\title{
UNIVERSAL PRAGMATICS: MEMPERTIMBANGKAN HABERMAS DALAM PENELITIAN LINGUISTIK
}

\author{
Makyun Subuki \\ UIN Syarif Hidayatullah Jakarta, Indonesia \\ E-mail: de_makyun@yahoo.co.id
}

\begin{abstract}
The aim of this writing was to describe the Habermas theoretical dimension named the universal pragmatics and its contribution in linguistic-especially, critical linguistic-research. In this research, this writer used the library research concerning to the Habermas philosophical and critical ideas. The result showed that, firstly, the universal pragmatics was part of Frankfurt School critical theory which influenced almost all of Habermas social and philosophical thinking. Secondly, the universal pragmatics was the new epistemological basis of pragmatics as science. And thirdly, Habermas tried to enlarging the pragmatics as not the only historicalhermeneutics, but also critical-reflective science.
\end{abstract}

Keywords: universal pragmatism; speech act; historical-hermeneutics; critical-reflective

\begin{abstract}
Abstrak: Tulisan ini bertujuan mendeskripsikan dimensi teoretis teori Pragmatik Universal yang dikembangkan oleh Habermas dan sumbangan yang diberikannya bagi penelitian linguistik terutama linguistik kritis. Dalam mewujudkan tujuan tersebut, penulis mengkaji sejumlah literatur yang terkait dengan ide pemikiran filosofis dan pemikiran kritis dari Habermas. Hasil penelitian ini menunjukkan tiga hal. Pertama, teori pragmatik universal merupakan bagian dari Teori Kritis yang dikembangkan Mazhab Frankfurt yang mempengaruhi hampir seluruh pemikiran sosial dan filsafat dari Habermas. Kedua, teori pragmatik universal merupakan usaha Habermas untuk memberikan dasar epistemologis dari disiplin pragmatik sebagai sebuah ilmu. Ketiga, melalui teori pragmatik universal ini, Habermas mencoba mengembangkan pragmatik tidak lagi sebagai ilmu yang semata-mata bersifat historis-hermeneutis, melainkan juga bersifat kritis-emansipatoris.
\end{abstract}

Kata Kunci: universal pragmatik; tindak-tutur; historis-hermeneutis; kritis-reflektif.

Permalink/DOI: http://dx.doi.org/10.15408/dialektika.v2i2.3623 


\section{Pendahuluan}

Jurgen Habermas merupakan salah satu pemikir Mazhab Frankfurt generasi kedua yang paling berpengaruh saat ini. Ia memiliki segi pemikiran yang sangat luas dan kompleks. Tulisannya terkait dengan berbagai persoalan, misalnya sosiologi, filsafat, politik, hukum, demokrasi, dan bahkan linguistik. Mengingat luasnya segi pemikiran Habermas, tulisan ini hanya akan membahas pemikiran Habermas di bidang bahasa dan kemungkinan untuk mempertimbangkannya dalam penelitian linguistik. Akan tetapi, hal inipun tidak mudah. Sebab, sebagaimana kita tahu, seluruh proyek pemikiran Habermas pada dasarnya saling terkait satu dengan yang lain. Oleh sebab itu, sebelum masuk ke pembahasan universal pragmatics, akan terlebih dulu melihat beberapa aspek pemikiran Habermas yang berhubungan dengannya.

\section{Pembahasan}

\section{Bahasa dalam Pertautan Pengetahuan dan Kepentingan}

Mengkaji pandangan Habermas tentang bahasa tampaknya tidak dapat sepenuhnya dilepaskan dari pendapat Habermas tentang pertautan pengetahuan dan kepentingan. Secara serampangan, disimpulkan bahwa, menurut Habermas, terdapat tiga jenis kepentingan yang mendasari tiga jenis ilmu pengetahuan. Pertama, kepentingan teknis dalam ilmu empiris analitis. Pembicaraan tentang jenis kepentingan ini pada dasarnya terkait prosedur metodologi Kant dalam mengembangkan pemikiran epistemologinya yang dimutlakkan oleh kaum positivisme logis. Akibatnya, di tangan positivisme logis, teori seolah-olah terlepas dari kehidupan sosial dan kebal terhadap hubungan intersubjektif; dan fakta direduksi menjadi "apa yang dapat dialami secara inderawi”.

Persoalan ini mula-mula dikritik oleh Peirce yang menunjukkan bahwa kemajuan yang dihasilkan oleh penelitian saintifik telah mendorong kita sebagai subjek untuk mempercayai bahwa teori tersebut memiliki kesahihan transendental, yang akan mampu mengungkapkan sesuatu fakta yang belum diuji. Kepercayaan tersebut lambat laun mendorong kita untuk mengorientasikan tingkah laku kita sesuai dengan harapan kita terhadap kepercayaan tersebut, sehingga kita memperlakukan objek sesuai dengan kepercayaan tersebut secara instrumental. Dalam penelitian, tindakan

${ }^{1}$ Fransisco Budi Hardiman, Kritik Ideologi: Pertautan Pengetahuan dan Kepentingan, (Jogjakarta: Kanisius, 1990), h. $128 \& 131$. 
instrumental, yang salah satunya diwujudkan melalui eksperimen, juga dipengaruhi oleh kepercayaan tersebut, sehingga dapat dikatakan bahwa tingkah laku kita terhadap objek penelitian diarahkan oleh sebuah kepentingan kognitif yang berupa kepercayaan. Selain itu, kepentingan kognitif yang mengarahkan penelitian kita ini terkait dengan kepentingan menguasai alam secara teknis. Oleh karena itu, Habermas menyebut jenis kepentingan dalam ilmu empirisanalitis sebagai kepentingan teknis. ${ }^{2}$

Kedua, kepentingan praktis dalam ilmu historis-hermeneutis. Dalam hal ini, kita perlu mempertimbangkan perbedaan ilmu historis-hermeneutis dengan ilmu empiris-analitis. Menurut Dilthey pembedaan keduanya terletak pada orientasi subjek pengetahuan, yaitu sikap subjek terhadap objek. Dalam ilmu empiris-analitis, pengalaman dikonstruksikan, yaitu digunakan sebagai teori untuk mengantisipasi peristiwa alamiah; sedangkan dalam ilmu historishermeneutis, pengalaman ditransposisikan, yaitu hasil objektivasi mental dipindahkan kembali ke dalam pengalaman reproduktif. Objektivasi mental itu sendiri terkait dengan konsep Dilthey yang memahami produk budaya sebagai pikiran objektif (objective mind), yaitu sekelompok satuan kehidupan (the community of life unities) yang merupakan totalitas objektivasi manusia terhadap berbagai hal, seperti sejarah, kebudayaan, dan masyarakat.

Selanjutnya, perbedaan mendasar lain antara ilmu empiris analitis dan ilmu historis hermeneutis terletak dalam cara mengungkapkan pengalaman. Ilmu empiris-analitis menggunakan bahasa yang ketat dan bebas dari unsur subjektivitas, sehingga pengalaman dapat diarahkan sesuai dengan proposisi abstrak. Sebaliknya, ilmu historis-hermeneutis menggunakan bahasa sehari-hari yang digunakan dalam komunikasi, sehingga pemahaman terhadap kehidupan konkret menjadi mungkin. Akan tetapi, hal ini melahirkan persoalan tentang bagaimana menempatkan bahasa sehari-hari dalam konteks pemahaman pikiran objektif. Untuk itu, Dilthey mengemukakan konsep lingkaran hermeneutis, yaitu bahwa untuk memahami bagian-bagian kita harus memiliki pengertian terlebih dahulu tentang keseluruhan dan untuk memahami keseluruhan kita harus memahami dulu bagian-bagiannya. Pemahaman hermeneutis ini dibimbing oleh kepentingan kognitif yang bertujuan mencapai konsensus untuk menghindari kemacetan dalam komunikasi. Kepentingan kognitif ini selanjutnya mengarahkan pemahaman dan tingkah laku praktis dalam komunikasi. Dari sini, Habermas menyimpulkan bahwa, serupa dengan

\footnotetext{
${ }^{2}$ Fransisco Budi Hardiman, Kritik Ideologi: Pertautan..., h. 144.
} 
tindakan instrumental yang mengarahkan kepentingan kognitif-teknis dalam ilmu empiris-analitis, konsensus mengarahkan kepentingan kognitif-praktis ilmu historis-hermeneutis yang merupakan hasil sistematisasi dari proses belajar interaktif-simbolis masyarakat terhadap pemahaman timbal balik dalam tingkah laku tindakan komunikatif.

Ketiga, kepentingan emansipatoris dalam ilmu kritis-reflektif. Berbeda dari dua kepentingan sebelumnya yang terkait secara tidak langsung dengan pengetahuan, kepentingan emansipatoris terkait langsung dengan pengetahuan, yaitu pengetahuan tentang diri yang berasal dari refleksi. Sebab, kepentingan teknis dan praktis pada dasarnya berasal dari kepentingan emansipatoris. Jenis pengetahuan yang dibimbing oleh kepentingan teknis dan praktis pada dasarnya lahir dari rasio yang berkehendak membebaskan diri dari kendala alamiah dan kendala interaksi sosial. Akan tetapi, teori yang dihasilkan kedua teori tersebut adakalanya membeku menjadi ideologi, sehingga kepentingan emansipatoris membimbing refleksi untuk menghancurkan dogmatisme dan ideologi dalam perwujudannya.

Bagi Habermas, arah sejarah ditentukan oleh proses produksi diri dalam kategori kerja dan pembentukan diri dalam kondisi komunikasi yang terdistorsi. Dalam hal kerja, Habermas mempertimbangkan Marx yang mencoba memahami konsep kesadaran palsu dalam kaitannya dengan perkembangan alat produksi. Akan tetapi, ia menolak konsepsi Marx tentang sejarah sebagai penataan fisik atas tindakan instrumental. Habermas justru mempertimbangkan Freud yang menganggap sejarah merupakan penataan fisik atas tindakan komunikatif yang merupakan penekanan atas dominasi alam bawah sadar. Pada akhirnya, Habermas mempertimbangkan bagaimana saluran komunikasi dapat dimanfaatkan untuk melakukan emansipasi masyarakat. Inilah kepentingan yang diemban oleh ilmu kritis yang mencoba membangkitkan kesadaran diri kelompok sosial sehingga dapat membebaskan diri dari belenggu ideologis yang melekat pada anggotanya.

Dari penjelasan di atas, kita dapat melihat bahwa bahasa memainkan peranan penting dalam ketiga jenis kepentingan tersebut, dan terutama dalam kaitannya dengan kepentingan praktis ilmu historis-hermeneutis dan kepentingan emansipatoris ilmu kritis-reflektif: dan dengan begitu kita dapat melihat secara tersirat alasan ketertarikan Habermas terhadap persoalan bahasa. Namun demikian, kita belum dapat menangkap bagaimana Habermas 
memandang persoalan bahasa dalam kehidupan sosial secara lebih luas dan dalam.

\section{Universal Pragmatics}

Sebagaimana dikemukakan McCharthy, ${ }^{3}$ pemikiran Habermas mengenai komunikasi pada dasarnya merupakan usaha terencana untuk memikirkan ulang landasan-landasan persoalan teori-praktik yang pada dasarnya juga telah coba dipecahkan oleh generasi Mazhab Frankfurt sebelumnya. Proyek pemikiran Habermas dalam hal ini terkait dengan kemungkinan menjelaskan komunikasi, baik secara teoretis dan normatif, yang melampaui hermeneutika murni tanpa harus tereduksi menjadi ilmu empiris-analitis yang ketat. Oleh sebab itu, seperti akan menjadi lebih jelas kemudian, agaknya penekanan terhadap komunikasilah yang membangkitkan Habermas untuk turut andil mempersoalkan bahasa dan komunikasi. Dengan kata lain, pembahasan mengenai bahasa terkait dengan komunikasi sebagai salah satu cara nir-kekerasan bagi masyarakat untuk melakukan emansipasi berupa pembebasan diri dari setiap dominasi: dan inilah tugas utama dari teori kritis.

Pandangan Habermas tentang bahasa meliputi banyak aspek teoritis yang merupakan dialog dengan pandangan tokoh lainnya tentang hal yang sama. Pertama, Habermas mengkritik pendekatan "analisis logis bahasa" yang dimulai dari Carnap- cenderung membatasi fokus mereka pada persoalan sintaksis dan semantik bahasa yang diabstraksikan dari dimensi pragmatisnya. Terdapat kecenderungan dalam linguistik untuk memapankan fonetik, sintaksis, dan semantik sebagai objek kajian utama dan memposisikan pragmatik sebagai domain penelitian empiris bahasa. Dalam hal ini, menurut Habermas, ${ }^{6}$ terjadi karena adanya semacam kekeliruan dalam mengabstraksi (abstractive fallacy). Habermas pada dasarnya tidak menolak abstraksi bahasa (langue) yang diasalkan kepada pemakaian bahasa dalam tuturan (parole). ${ }^{7}$ Ia hanya menegaskan pembedaan semacam itu tidak mencukupi untuk menjamin bahwa dimensi pragmatis bahasa, yang darinya abstraksi dilakukan, dapat dimasuki analisis formal atau linguistik.

\footnotetext{
${ }^{3}$ Thomas McCarthy, The Critical Theory of Jurgen Habermas, (Massachusset: The Massachusset Institute of Technology Press, 1978), h. 273.

${ }^{4}$ Thomas McCarthy, The Critical Theory..., h. 273.

${ }^{5}$ Thomas McCarthy, The Critical Theory..., h. 273.

6 Jurgen Habermas, On the Pragmatics of Communication, (Massachusset: The Massachusset Institute of Technology Press, 1998), h. 27.

${ }^{7}$ Jurgen Habermas, On the Pragmatics of Communication..., h. 27.
} 
Habermas lebih jauh juga menolak cara Chomsky membedakan antara competence dan performance. Bagi Habermas, Chomsky tidak berbeda dengan Carnap. Sebab, ia mereduksi competence, pengetahuan ideal penutur-pendengar akan bahasanya sendiri, terbatas pada kompetensi linguistik. Lebih dari itu, yang diketahui penutur-pendengar ideal tentang bahasanya -yang memungkinkan mereka menggunakan dan memahaminya- sejauh ini dibatasi pada komponen fonetik, sintaksis dan semantik yang direkonstruksi secara formal dan substantial ke dalam teori bahasa universal. ${ }^{8}$

Konsep Habermas tentang pragmatik universal tidak hanya terkait dengan ciri fonetik, sintaksis, dan semantik kalimat saja, melainkan juga ciri pragmatis tuturan tertentu. Hal ini berarti bahwa bukan hanya kompetensi linguistik saja yang dapat direkonstruksi secara rasional dan universal, melainkan juga kompetensi komunikatif.' Habermas mengemukakan,

The aim of reconstructive linguistic analysis is the explicit description of the rules that a competent speaker must master in order to form grammatical sentence and to utter them in an acceptable way. . the assumption is that communicative competence has just as universal a core as linguistic competence. ${ }^{10}$

Dalam membahas kompetensi komunikatif ini, Habermas, sebagaimana dikemukakan oleh McCarthy mengikuti pendapat Austin dan Searle tentang tindak tutur (speech act). Dengan mengikuti jalan berpikir Searle, Habermas memandang tindak tutur sebagai unit dasar komunikasi linguistik. ${ }^{11}$ Tindak tutur merupakan produksi kalimat di bawah kondisi tertentu, yaitu perwujudan kalimat dalam bentuk tuturan. Secara umum, terdapat dua hal yang dapat dianalisis dalam tuturan, yaitu muatan proposisional (propositional content) dan daya ilokusioner (illocutionary force). Muatan proposisional, yang memapankan hubungan komunikasi dengan dunia objek dan peristiwa, pada dasarnya merupakan kalimat yang tergantung (dependent sentence) kepada kalimat yang mendominasi (dominating sentence), yaitu kalimat yang memapankan kekuatan ilokusioner tuturan, cara berkomunikasi antara penutur dan pendengar, dan juga situasi pragmatisnya. ${ }^{12}$ Sebagai contoh, dalam tuturan Saya menyatakan bahwa p, saya berjanji bahwa p, dan Saya memerintahkan $p$

\footnotetext{
${ }^{8}$ Thomas McCarthy, The Critical Theor..., h. 274.

${ }^{9}$ Thomas McCarthy, The Critical Theor..., h. 274.

${ }^{10}$ Jurgen Habermas, On the Pragmatics..., h. 47.

${ }^{11}$ Thomas McCarthy, The Critical Theory..., h. 275.

${ }^{12}$ Thomas McCarthy, The Critical Theory..., h. 275-276.
} 
muatan proposisional yang sama $(p)$ tampak memiliki berbagai kekuatan ilokusioner. Dengan kata lain, setiap tuturan terdiri atas dua kalimat: yaitu kalimat yang mendominasi dan kalimat yang berisi muatan proposisional. Dengan demikian, bagi Habermas, kompetensi penutur ideal bukan hanya meliputi kemampuan untuk memproduksi dan memahami kalimat gramatikal, melainkan juga kemampuan untuk menempatkan dan memahami cara komunikasi berlangsung dan hubungannya dengan dunia eksternal di mana tuturan dalam bahasa biasa menjadi mungkin. ${ }^{13}$

Lebih jauh, McCarthy mengemukakan bahwa apabila kita hendak menempatkan pragmatik universal dalam peta semiotik, kunci perbedaannya adalah antara aturan pembentukan kalimat dalam segala bahasa (teori gramatikal) pada satu sisi dan aturan penggunaan kalimat dalam suatu tuturan (pragmatik universal). ${ }^{14}$ Sebab, seperti kata Habermas sendiri, produksi kalimat secara gramatikal memiliki aturan yang berbeda dari bagaimana memakai kalimat menurut aturan pragmatik yang membentuk infrastruktur situasi tuturan secara umum. ${ }^{15}$ Habermas berpendapat bahwa ketika dituturkan, kalimat harus ditempatkan dalam kaitannya dengan tiga hal: (1) realitas-luar, yaitu dunia objek dan peristiwa yang tentangnya orang dapat membuat pernyataan benar atau salah; (2) realitas-dalam, yaitu dunia pengalaman yang diekspresikan secara intensional oleh penutur; dan (3) realitas normatif, yaitu dunia sosiokultural yang terdiri atas nilai dan norma serta peran dan aturan. ${ }^{16}$

Berdasarkan penjelasan di atas, dapat dipahami kiranya bahwa, selain harus dapat membentuk kalimat secara gramatikal (kompetensi linguistik), kompetensi komunikatif terkait dengan tiga hal, yaitu (1) penutur memiliki kemampuan untuk memilih muatan proposisional yang dapat merepresentasikan suatu pengalaman atau fakta dengan tepat, sehingga pendengar dapat memperoleh pengetahuan darinya; (2) penutur memiliki kemampuan untuk menggunakan ekspresi linguistik yang dapat menunjukkan maksud yang bersangkutan secara akurat, sehingga pendengar dapat mempercayai penutur; dan (3) penutur memiliki kemampuan untuk melakukan suatu speech act yang dapat memenuhi norma-norma dan citra diri yang diakui,

\footnotetext{
${ }^{13}$ Jurgen Habermas, On the Pragmatics..., h. 48.

${ }^{14}$ Thomas McCarthy, The Critical Theory..., h. 279

${ }^{15}$ Jurgen Habermas, On the Pragmatics..., h. 48.

${ }^{16}$ Jurgen Habermas, On the Pragmatics..., h. 49.
} 
sehingga pendengar dapat setuju dengan penutur dalam hal nilai-nilai yang dianutnya. ${ }^{17}$

Bagaimanapun juga, kita dapat melihat bahwa kompetensi komunikatif yang merupakan aspek analisis dari konsep pragmatik universal Habermas ini berkoresponden dengan tiga macam fungsi pragmatis yang dikemukakannya, yaitu fungsi representatif, ekspresif, dan interaktif. ${ }^{18}$ Fungsi pertama, yang terkait dengan klaim kebenaran yang melekat secara implisit dalam wicara, merupakan analisis tentang syarat universal dan wajib yang tidak bergantung pada konteks dan tidak bersifat variabel dalam membuat pernyataan tentang dunia. Fungsi kedua, fungsi kedua, yang terkait dengan klaim keterpercayaan dan ketulusan hati, merupakan analisis tentang syarat universal dan wajib dalam mengekspresikan pengalaman intensional dunia seseorang dalam kaitannya dengan representasi subjektivitasnya secara transparan. Fungsi ketiga, yang terkait dengan klaim ke-benar-an dan ketepatan, merupakan analisis tentang syarat universal dan wajib bagi penempatan hubungan interpersonal yang melanggengkan dunia kita secara linguistik, suatu dunia yang dimiliki bersama yang didasarkan atas resiprositas harapan. ${ }^{19}$

Sejatinya, sebagaimana dikemukakan oleh pragmatik universal Habermas merupakan pengembangan teori tindak tutur Austin dan Searle. ${ }^{20}$ Oleh sebab itu, mengikuti Austin dan Searle, analisis Habermas mengambil bentuk investigasi tentang syarat yang diperlukan bagi keberhasilan suatu tindak tutur. Keberhasilan dalam hal ini bukan semata persoalan keterpahaman (comprehendsability) secara linguistik namun juga soal keberterimaan (acceptability): dengan tindak ilocutioner, seorang penutur menawarkan sesuatu yang dapat diterima atau ditolak. Hanya saja, apabila Searle menekankan pembicaraannya pada tindak tutur yang bersifat institusional (misalnya pada pernikahan, peresmian, pembaptisan), Habermas justru menekankan pada tindak tutur yang tidak bersifat institusional. Dalam tindak tutur yang bersifat institusional, daya ilokusioner dapat langsung dilacak pada kekuatan normanorma pengikat yang telah mapan. Adapun dalam tindak tutur yang tidak institusional, daya ilokusioner justru berasal dari kemauan yang jujur si penutur untuk memasuki suatu hubungan, menerima kewajiban, dan menanggung akibat dari tindakan yang dilakukannya.

\footnotetext{
${ }^{17}$ Jurgen Habermas, On the Pragmatics..., h. 50.

${ }^{18}$ Jurgen Habermas, On the Pragmatics..., h. 54.

${ }^{19}$ Thomas McCarthy, The Critical Theory..., h. 281.

${ }^{20}$ Thomas McCarthy, The Critical Theory..., h. 282.
} 
Dalam pada itu, Habermas mengklasifikasi tiga macam tindak tutur -dan hal ini dapat juga kita hubungkan dengan tiga macam kompetensi komunikatif dan tiga macam fungsi pragmatik-, yaitu konstatif (constative), regulatif (regulative), dan avowal. ${ }^{21}$ Tindak tutur konstatif atau asertif (assertive) berkaitan dengan nilai benar-salah ujaran yang dilandasi oleh syarat kebenaran, dan hal ini terkait erat dengan fungsi pragmatis-representatif. Tindak tutur regulatif (regulative) merupakan tindak-tutur yang bertujuan mempengaruhi hubungan seseorang dengan orang lainnya atau kelompok tertentu dan dilandasi oleh syarat kepatutan (appropriateness), dan hal ini terkait erat dengan fungsi pragmatis-interaktif. Tindak tutur avowals merupakan tindak tutur yang bertujuan menggambarkan kondisi internal diri penutur dan disyaratkan oleh ketulusan (sincerity), kejujuran (truthfulness), dan hal ini terkait erat dengan fungsi pragmatis-ekspresif.

Masih dalam kaitannya dengan tiga macam tindak tutur dan tiga macam fungsi pragmatis tuturan tersebut, Habermas berpendapat tentang jenis wacana (discourse) yang merupakan bentuk komunikasi tempat pernyataan penutur diuji melalui argumen sistematis. Argumen sistematis yang di maksud yaitu, pertama, wacana teoretis (theoretical discourse), berkaitan dengan fakta-fakta yang mendukung kebenaran suatu pernyataan; kedua, wacana praktis (practical discourse), berkaitan dengan norma, yaitu tentang kepatutan dalam negoisasi; dan ketiga, wacana metateoretis (metatheritical discourse) yang mempermasalahkan fakta atau norma yang patut bagi situasi tertentu dan wacana metaetis (metaethical discourse) yang mempermasalahkan pengetahuan sebagai pengetahuan, yaitu mempermasalahkan prosedur yang digunakan dalam menggeneralisasi sebuah pengetahuan yang berlaku dalam masyarakat. ${ }^{22}$ Namun demikian, kiranya perlu dipahami bahwa, bagi Habermas, wacana yang menjadi tempat bagi realisasi dan sekaligus tempat berkontestasi setiap jenis speech act hanya dapat terwujud dalam suatu situasi wicara yang ideal. Dalam hal ini, situasi wicara yang ideal tersebut mencakupi tiga hal: (1) kebebasan bicara tanpa halangan; (2) kesamaan hak untuk bicara; dan (3) distribusi kuasa secara merata dalam setiap strata masyarakat. ${ }^{23}$

\footnotetext{
${ }^{21}$ Jurgen Habermas, On the Pragmatics..., h. 81.

${ }^{22}$ Stephen W. Littlejohn, Theories of Human Communication (edisi ketujuh), (Belmont: Wadsworth/Thomson Learning, 2002), h. 215.

${ }^{23}$ Stephen W. Littlejohn, Theories of Human..., h. 216.
} 


\section{Universal Pragmatics dalam Penelitian Linguistik}

Sejak Austin menerbitkan How to Do Things with Words, seperti diungkap oleh Marmaridou, pragmatik menjadi bidang kajian yang telah sangat berkembang dan telah melahirkan beragam topik pembahasan yang sangat menarik, di antaranya adalah prinsip kerja sama (cooperative principle) dan dua macam implikatur (yaitu implikatur konvensional dan implikatur konversasional) yang dikemukakan oleh Grice, teori relevansi yang dikembangkan oleh Sperber dan Wilson sebagai kritik atas pendapat Grice mengenai prinsip kerja sama dan implikatur, prinsip kesantunan yang dikemukakan oleh Leech dan merupakan pembelaan terhadap Grice dari kritik Sperber dan Wilson. ${ }^{24}$ Akan tetapi, sangat disayangkan bahwa selain Searle, tidak ada yang membuat suatu bahasan filosofis yang cukup memadai bagi status ilmiah disiplin ilmu tersebut.

Berdasarkan kenyataan tersebut, agaknya kita harus memperhitungkan bahwa sumbangan pertama yang diberikan Habermas melalui pragmatik universal adalah bahwa dia memberikan sebuah basis epistemologis yang lebih kokoh bagi pragmatik sebagai sebuah disiplin ilmu. Tentu saja, ada kelemahan dalam cara Habermas membicarakan status epistemologis bagi pragmatik. Dengan mengutip pendapat Putnam, Cummings, misalnya, menganggap bahwa penjelasan Habermas tentang pragmatik universal bukan saja sulit dipahami, melainkan juga berpotensi menjadi nalar yang sama dengan positivisme yang justru dia kritik. ${ }^{25}$

Selain memberikan basis epistemologis, keterlibatannya dalam proyek teori kritis telah memberikan warna tersendiri dari setiap pemikirannya. Begitu pula yang terjadi pada pragmatik. Cummings mengemukakan bahwa situasi wicara ideal yang dikemukakan Habermas, yang menjadi sarana terwujudnya konsensus rasional, pada dasarnya sangat sulit atau bahkan tidak mungkin dapat diwujudkan dalam kenyataan. ${ }^{26}$ Akan tetapi, menurut Cummings hal ini sudah cukup bagi Habermas untuk dijadikan landasan moral praktik teori kritisnya. Oleh sebab itu, apabila kita bermaksud menggunakan teori pragmatik universal Habermas dalam penelitian pragmatik, baik sebagai aplikasi murni maupun dalam rangka kritik, kita dapat memperluas wilayah kajian pragmatik menjadi ilmu kritis-reflektif yang dapat diarahkan demi kepentingan emansipatoris. Hal

\footnotetext{
${ }^{24}$ Asim Gunarwan, Dari Pragmatik ke Pengajaran Bahasa (Makalah Seminar Bahasa dan Sastra Indonesia dan Daerah), (IKIP Singaraja, 2004), h. 8.

${ }^{25}$ Louise Cummings, Pragmatik: Sebuah Pendekatan Multidisipliner (Terjemahan Pragmatics: A Multidisciplinary Perspective oleh Eti Setiawati et al.), (Yogyakarta: Pustaka Pelajar, 1999/2007), h. 298.

${ }^{26}$ Louise Cummings, Pragmatik: Sebuah Pendekatan. . . . , h. 298.
} 
itu berarti bahwa Habermas dengan sengaja telah mengarahkan pragmatik -atau lebih tepatnya universal pragmatics- sebagai ilmu yang tidak semata-mata bersifat historis hermeneutis, melainkan juga bersifat kritis-reflektif.

Tentu saja ini bukan hal yang benar-benar baru saat ini. Tradisi analisis wacana kritis telah juga mengarahkan kajian linguistik menjadi disiplin ilmu yang bersifat kritis. Akan tetapi, persoalannya, pada analisis wacana kritis, persoalan epistemologis tentang disiplin linguistik yang dapat dimasuki oleh analisis formal dan logis tidak dibicarakan. Dengan kata lain, kajian analisis wacana kritis tidak sampai mempersoalkan apakah disiplin tersebut merupakan disiplin yang juga sama dengan fonetik, sintaksis, dan semantik yang dapat dianalisis secara formal dan logis. Habermas melakukan yang sebaliknya. Sebelum ia mentransformasikan pragmatik sebagai ilmu kritis-reflektif, ia bergumul dulu dengan status ilmiah pragmatik. Bagi Habermas, sebagaimana telah dikemukakan di atas melalui konsep kompetensi komunikatif dalam universal pragmatics, pragmatik memiliki klaim ilmiah yang sama universalnya dan dengan demikian dapat dianalisis secara logis dan formal- sebagaimana klaim yang dimiliki fonetik, sintaksis, dan semantik.

\section{Simpulan}

Berdasarkan uraian di atas, setidaknya ada tiga hal yang disimpulkan dalam tulisan ini. Pertama, universal pragmatics pada dasarnya merupakan fase lanjut pemikiran Habermas sebagai bagian dari pemikir Mazhab Frankfurt, sehingga nalar emansipatoris dalam teori ini masih dapat dilihat dengan jelas. Kedua, melalui pragmatik universal ini Habermas memberikan dasar epistemologis bagi pragmatik sebagai disiplin ilmu yang memiliki keilmiahan yang sederajat dengan bidang linguistik lainnya, seperti fonetik, sintaksis, dan semantik. Hanya saja, penjelasan yang dilakukan dalam rangka menjustifikasi hal tersebut dapat berakibat kepada nalar positivistik yang justru kerap ia kritik. Ketiga, melalui proyek pragmatik universal ini juga Habermas memperluas nalar dan wilayah kajian pragmatik, dari disiplin yang semata-mata bersifat historishermeneutis menjadi disiplin yang juga bersifat kritis reflektif. 


\section{Daftar Pustaka}

Cummings, Louise. Pragmatik: Sebuah Pendekatan Multidisipliner (Terjemahan Pragmatics: A Multidisciplinary Perspective oleh Eti Setiawati et al.). Yogyakarta: Pustaka Pelajar, 1999/2007.

Habermas, Jurgen. On the Pragmatics of Communication. Massachusset: The Massachusset Institute of Technology Press, 1998.

Hardiman, Fransisco Budi. Kritik Ideologi: Pertautan Pengetahuan dan Kepentingan. Jogjakarta: Kanisius, 1990.

Littlejohn, Stephen W. Theories of Human Communication (edisi ketujuh). Belmont: Wadsworth/Thomson Learning, 2002.

McCarthy, Thomas. The Critical Theory of Jurgen Habermas. Massachusset: The Massachusset Institute of Technology Press, 1978. 